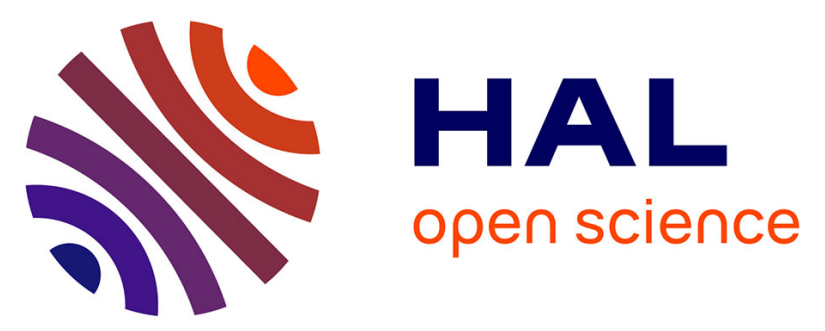

\title{
Phylogeny and diversification of the cloud forest Morpho sulkowskyi group (Lepidoptera, Nymphalidae) in the evolving Andes
}

Romain Nattier, Claire Capdevielle-Dulac, Catherine Cassildé, Arnaud Couloux, Corinne Cruaud, Gilbert Lachaume, Gerardo Lamas, Jean-François Silvain, Patrick Blandin

\section{To cite this version:}

Romain Nattier, Claire Capdevielle-Dulac, Catherine Cassildé, Arnaud Couloux, Corinne Cruaud, et al.. Phylogeny and diversification of the cloud forest Morpho sulkowskyi group (Lepidoptera, Nymphalidae) in the evolving Andes. Zoologica Scripta, 2016, 10.1111/zsc.12226 . hal-01416573

\section{HAL Id: hal-01416573 \\ https://hal.sorbonne-universite.fr/hal-01416573}

Submitted on 14 Dec 2016

HAL is a multi-disciplinary open access archive for the deposit and dissemination of scientific research documents, whether they are published or not. The documents may come from teaching and research institutions in France or abroad, or from public or private research centers.
L'archive ouverte pluridisciplinaire HAL, est destinée au dépôt et à la diffusion de documents scientifiques de niveau recherche, publiés ou non, émanant des établissements d'enseignement et de recherche français ou étrangers, des laboratoires publics ou privés. 
1 Romain Nattier, Institut de Systématique, Evolution, Biodiversité, ISYEB - UMR 7205

2 CNRS MNHN UPMC EPHE, Muséum national d'Histoire naturelle, Sorbonne Universités,

357 rue Cuvier CP50, 75005 Paris, France, nattier@mnhn.fr

4

5 Phylogeny and diversification of the cloud forest Morpho sulkowskyi group (Lepidoptera,

6 Nymphalidae) in the evolving Andes

7

8 ROMAIN NATTIER

9 CLAIRE CAPDEVIELLE-DULAC

10 CATHERINE CASSILDÉ

11 ARNAUD COULOUX

12 CORINNE CRUAUD

13 GILBERT LACHAUME

14 GERARDO LAMAS

15 JEAN-FRANÇOIS SILVAIN

16 PATRICK BLANDIN

17

18 Short running title: Diversification of a cloud forest butterfly in the Andes

19 Nattier, R. et al. 
Nattier, R. et al. (2016) Phylogeny and diversification of the cloud forest Morpho sulkowskyi group (Lepidoptera, Nymphalidae) in the evolving Andes. Zoologica Scripta, 00, 000-000. The monophyletic Morpho sulkowskyi butterfly group, endemic of Andean cloud forests, was studied to test the respective contributions of Mio-Pliocene intense uplift period and Pleistocene glacial cycles on Andean biodiversity. We sampled nine taxa covering the whole geographical range of the group. Two mitochondrial and two nuclear genes were analysed using a Bayesian method. We established a dated phylogeny of the group using a relaxed clock method and a wide-outgroup approach. To discriminate between two hypotheses, we used a biogeographical probabilistic method. Results suggest that the ancestor of the Morpho sulkowskyi group originated during the Middle-Late Miocene uplift of the Eastern Cordillera in northern Peru, consistent with the divergence time of the Chusquea bamboos, the present hostplants of the group. Biogeographical inference suggests that the $M$. sulkowskyi and $M$. lympharis clades diverged in the northern Peruvian Andes. The subsequent divergences, from the Late Miocene to the Late Pliocene, should have resulted from a dispersal towards the Northern Andes (M. sulkowskyi clade), after the closure of the West Andean Portal separating the Central and Northern Andes, and a southwards dispersal along the Peruvian and Bolivian Eastern Cordilleras (M. lympharis clade). Only a few divergences occurred at the very end of the Pliocene or during the Pleistocene, a period when the more recent uplifts interfered with Pleistocene glacial cycles. Romain Nattier, Institut de Systématique, Evolution, Biodiversité, ISYEB - UMR 7205 CNRS MNHN UPMC EPHE, Muséum national d'Histoire naturelle, Sorbonne Universités, 57 rue Cuvier CP50, 75005 Paris, France.E-mail nattier@mnhn.fr 


\section{INTRODUCTION}

The Tropical Andes, the richest and most diverse region on Earth (Mittermeier et al., 2004), are a good example of interactions between mountain building and diversification processes that decisively affected present biodiversity patterns (Hoorn et al., 2013). To explain the diversification of floras and faunas throughout the vast and complex Andean mountains, different processes were considered, including dispersal and subsequent diversification driven by the rise of mountain ranges that create connections, barriers and new ecological belts, as well as more recent cycles of areas fragmentation and expansion driven by Pleistocene climatic oscillations (e.g., Descimon, 1986; Pennington \& Dick, 2004; Wahlberg \& Freitas, 2007; Antonelli et al., 2009; Couvreur et al., 2011; Condamine et al., 2012; Blandin \& Purser, 2013). That recent processes (Pleistocene glacial cycles) played a major role, or not, in the diversification of Andean lineages is a matter of debate (Rull, 2008, 2014, Garzón-Orduña et al., 2014, 2015). Various studies, based on robust time-calibrated phylogenies, demonstrated that several plant and animal lineages diversified during the Mio-Pliocene intense uplift period (e.g., Chaves et al., 2011; Fiedler \& Strutzenberger, 2013; Castroviejo-Fisher et al., 2014; Luebert \& Muller, 2015; Sanín et al., 2016). However, the role of Pleistocene geoclimatic dynamism has been suggested by other studies (e.g., García-Moreno et al., 1999; Chesser, 2000; Casner \& Pyrcz, 2010). As suggested by meta-analyses, the Mio-Pliocene and Pleistocene hypotheses are complementary (Turchetto-Zolet et al., 2013; Rull, 2014).

Several works on diversification in the Andes focussed on butterflies or moths (e.g., Adams, 1985; Descimon, 1986; Willmott et al., 2001; Hall, 2005; Elias et al., 2009; Casner \& Pyrcz, 2010; Strutzenberger \& Fiedler, 2011; Matos-Maraví et al., 2013; De-Silva et al., 2016). The diversification of the Neotropics-endemic genus Morpho Fabricius, 1807 (Nymphalidae), that includes the emblematic, metallic blue butterflies, was studied by Penz et al. (2012), and its relation with the geodynamics of the Andes was discussed by Blandin \& Purser (2013). This monophyletic genus (Cassildé et al., 2010, 2012; Penz et al., 2012) originated at ca. $32 \mathrm{Ma}$ (Wahlberg et al., 2009) in the east side of the proto-Andes (Penz et al., 2012) and Blandin \& Purser (2013). The genus diversified into species living in lowland forests, low mountain forests, and cloud forests, during a period of major and complex orogenic processes, high elevations being attained at different times in Central Andes and Northern Andes, as well as in western and eastern cordilleras (Garzione et al., 2008; Sempere et al., 2008; Eude et al., 2015). In order to discriminate between the Mio-Pliocene and Pleistocene diversification 
hypotheses, Andean-endemic cloud forest butterflies should provide ideal models, as they diversified within a single ecological belt that could develop only when cordilleras attained suitable elevations. We have selected a group of common butterflies, the Morpho sulkowskyi group, that includes closely related taxa distributed from Colombia to Bolivia at 1.8-3.5 km altitudes (Krüger, 1924; Schultze, 1928; Salazar, 1998; Prieto et al., 2005; personal observations in Bolivia and Peru - PB).

Here, we established a phylogeny to clarify the systematics of the group, and we used a dated phylogeny with distribution data to localize the origin of the group in time and space, and then to discriminate two biogeographical scenarios: 1) a recent vicariant diversification of a widespread species, as a result of the Pleistocene glacial cycles; 2) an older diversification, resulting from dispersal throughout the Andes driven by geodynamics processes, with two opposite predictions: i) origin in the Northern Andes (Colombia and Ecuador), with subsequent dispersal towards the Central Andes (Peru and Bolivia); or ii) origin in the Central Andes and dispersal towards the Northern Andes.

\section{MATERIAL AND METHODS}

\section{Taxonomy}

Morpho sulkowskyi Kollar, 1849 was described from Colombia. Several morphologically very similar taxa were subsequently described, which have been considered either as species or subspecies. Le Moult \& Réal (1962) identified one polytypic and five monotypic species, but Lamas (2004) recognized only two polytypic species and Blandin (1993, 2007) only one (Appendix S1). In the present state of knowledge, we recognize 11 taxa of the species-group: sulkowskyi Kollar, 1849 (Colombian cordilleras); lympharis Butler, 1873 (from southern Peru (Cuzco department) to Bolivia (La Paz department)); eros Staudinger, 1892 (Bolivia, Cochabamba department); sirene Niepelt, 1911 (eastern Ecuador); selenaris Le Moult \& Réal, 1962 (northern Peru, upper Huallaga valley, Huánuco department); stoffeli Le Moult \& Réal, 1962 (central Peru, Pasco and Junín departments); descimokoenigi Blandin, 1993 (southern Peru, Cuzco department); nieva Lamas \& Blandin, [2007] (northern Peru, Amazonas and San Martín departments); calderoni Blandin \& Lamas, [2007] (Amazonas department); achiras Fisher, 2009 (northern Peru, Abiseo National Park, San Martín department); zachi Schäffler \& Frankenbach, 2009 (northern Peru, San Martín department). Diagnostic characters are 
indicated and taxa are figured, with their geographical distribution, in Appendix S1.

\section{Field studies}

Three recently described taxa from northern Peru (calderoni Blandin \& Lamas, [2007], nieva Lamas \& Blandin, [2007], zachi Schäffler \& Frankenbach, 2009) were discovered on different slopes of the Eastern Cordillera in its northern part (Blandin \& Lachaume, 2014). We performed field surveys to check for the allopatry or, alternatively, the sympatry of these taxa. After a first survey which allowed us to locate a key area close to the Carretera Transandina near the border between the Amazonas and San Martín departments, specimens were collected along two parts of the upper Río Nieva, that are separated by a mountain range that this river cut across through a narrow gorge (Fig. 1, N1 \& N2). Specimens were also collected in neighbouring localities, notably in Oso Perdido (Amazonas) and El Afluente (San Martín) (Fig. 1, OP; EF). The collected specimens have been deposited either in the Museo de Historia Natural, Universidad Nacional Mayor de San Marcos (MUSM, Lima) or the Muséum National d'Histoire Naturelle (MNHN, Paris).

\section{Molecular sampling}

Field sampling along Río Nieva (Fig. 1, N1 \& N2) provided specimens of calderoni, nieva and zachi (deposited in the MNHN). Specimens as recent as possible of sulkowskyi Kollar, 1849 (Colombia: Central Cordillera, Medellín area, Antioquia department), sirene Niepelt, 1911 (Ecuador: Baños area, Tungurahua province), selenaris Le Moult \& Réal, 1962 (Peru: Carpish area, Huánuco department), lympharis Butler, 1873 (Peru: Pillahuata area, Cuzco department), descimokoenigi Blandin, 1993 (Peru: Cordillera Urubamba, Cuzco department), and eros Staudinger, 1892 (Bolivia: Incachaca area, Chapare, Cochabamba department) were selected from MNHN collections. There were no available specimens of stoffeli Le Moult \& Réal, 1962 (Junín department, Peru). The taxon achiras Fisher, 2009, from Abiseo National Park (San Martín department, Peru), could not be studied, as it is not represented in either MUSM or MNHN. Thus, we studied nine taxa and 91 specimens (Appendix S2a and Fig. 2), covering the whole geographical range of the group.

Total DNA was extracted from the legs or the abdomens of the specimens, using a Qiagen DNeasy Tissue kit. Two mitochondrial (Cytochrome oxidase 1 and Cytochrome b) and two 
nuclear (EF1a - translation elongation factor 1 alpha and RPS5 - ribosomal protein S5) DNA fragments were amplified by polymerase chain reaction. For additional information on sequencing protocols, see Appendix S3.

\section{Molecular phylogenetic analysis}

The sequences of the two mitochondrial genes were concatenated for each individual, since both are from mitochondrial DNA. To conduct Bayesian analyses, the substitution model of evolution was estimated using jMODELTEST v 2.1.4 (Darriba et al., 2012), and the Akaike information criterion corrected for small samples (AICc) (Akaike, 1973, 1974) was used to select the GTR+G model. Analyses were performed with MrBayes 3.2.2 (Ronquist \& Huelsenbeck, 2003). Four Markov chains were run simultaneously for 50 million generations, sampling every 1000 generations to ensure independence of samples. The first 10000 trees generated were discarded as burn-in and determined empirically from the log-likelihood values using TRACER V1.6 (Rambaut \& Drummond, 2007). The remaining trees were used to construct $50 \%$ majority-rule consensus trees. Two independent runs were performed to check whether convergence was reached on the same posterior distribution and whether the final trees converged on the same topology. The statistical confidence of each node was evaluated by posterior probabilities. Morpho anaxibia (Esper, [1801]) (sub-genus Iphixibia Le Moult \& Réal, 1962) was chosen as outgroup, as this species belongs to one of the two major Morpho clades (see Cassildé et al., 2012; Penz et al., 2012), while the Morpho sulkowskyi group belongs to the other.

\section{Dating analyses}

To minimize the effect of increased mutation rates at the intraspecific level in dating methods (Ho et al., 2005; Ho, 2007), we used the Poisson Tree Processes (PTP) model to infer putative species boundaries (Zhang et al., 2013). This method models speciation or branching events in terms of the number of substitutions, and can use the phylogenetic tree directly without needing the difficult and error prone procedures of time calibration required by other methods such as GMYC (Zhang et al., 2013). Analyses were conducted for CO1 gene using the PTP web server (http://species.h-its.org/ptp/) to select one individual per cluster for dating analyses. 
Because no suitable fossils for direct calibrations exist within our study group, and in order to be fully independent from regional geological knowledge, we attempted to use a balanced approach to calibrate our analyses using a wide-outgroup approach, which is considered to be a reasonable alternative (Hedges \& Kumar, 2004; Strijk et al., 2012). We extended a published dated genus-level dataset (Wahlberg et al., 2009) with our new sequences and sequences available in GenBank for several other Morpho species. The sampling for the dating analysis contained 31 Nymphalidae butterflies (including 17 Morpho species) and three DNA fragments (CO1, EF1a and RPS5) (Appendix S2b).

To improve the estimates of node ages, we used multiple calibration points (Lee, 1999; Wang et al., 1999; Sauquet et al., 2012) on basal and apical nodes. We also checked whether all calibration points were compatible with the reference topology. The dating analysis was conducted using five secondary calibration points (Wahlberg et al., 2009) with the entire dataset (Fig. 3A). The split between Calinaginae (Calinaga davidis Oberthür, 1881) and all other Nymphalidae was set at $75.7 \mathrm{Myr}$ (standard deviation: 7.9 Myr, node A), the split between Euxanthe Hübner, [1819] and Charaxes Ochsenheimer, 1816 at $18.1 \mathrm{Myr}$ (4.6 Myr, node B); the diversification of Satyrini at 52.1 Myr (6.4 Myr, node C); the split between Neope Moore, 1866 and Lethe Hübner, [1819] at 36.6 Myr (5.0 Myr, node D), and the diversification of Morphini + Brassolini at 48.5 Myr (5.0 Myr, node E). The calibration of the node D is consistent with fossil data; two fossil Lethe species are known, the age of the oldest being estimated at ca. $32 \mathrm{Myr}$ (Miller et al., 2012).

We used a normal distribution for the tree prior to node calibration, which is particularly suitable for modelling secondary calibration points (Ho, 2007), with the same standard deviation as the Highest Posterior Density (HPD) of Wahlberg et al. (2009). Calinaga davidis was set as a sister group of all the other species and calibration nodes were constrained on the topology, while all other relationships were left free to vary, so that topological uncertainty was incorporated into posterior estimates of divergence dates. We used the Bayesian relaxed phylogenetic approach, performed in BEAST 1.7.5 (Drummond et al., 2012), to estimate the relative age of divergence of the lineages studied. We partitioned the data by gene, with unlinked partitions according to the GTR $+\mathrm{G}$ substitution model for each and by codon for the CO1. We used the uncorrelated lognormal relaxed clock model and a Birth Death Process of speciation. We confirmed the results by using two independent analyses over 50 million generations, and sampled every 2500th generation. The two analyses converged on similar 
posterior estimates. We then used Tracer 1.6 (Drummond \& Rambaut, 2007) to assess convergence, measure the effective sample size of each parameter, and calculate the mean and 95\% HPD interval for divergence times. We assessed whether a sample size greater than 200 was achieved for all parameters after the analyses. Results of the two runs were combined with LogCombiner 1.7.5 (Drummond et al., 2012), and the Maximum Clade Credibility tree was compiled with TreeAnnotator 1.7.5 (Drummond et al., 2012).

\section{Biogeographical reconstructions}

To test the dispersal and subsequent speciation hypotheses, we used a probabilistic method implemented in LAGRANGE (Ree \& Smith, 2007) using biogeographical speciation scenarios and parameters for dispersal and extinction (Ree et al., 2005). Terminal taxa were assigned to one or several of the following geographical areas: COL (Colombian Cordilleras), EEQ (Ecuadorian eastern cordilleras), WNP (Western Cordillera in northern Peru), ENP (Eastern Cordillera in northern Peru), ECP (Eastern Cordillera in central Peru), ESPB (eastern cordilleras in southern Peru and Bolivia). We confined possible dispersals to adjacent areas only, specifically between the following combinations: COL-EEQ, EEQ-WNP, EEQ-ENP, ECP-WNP, ECP-ENP, ECP-ESPB. The BEAST chronogram was used for LAGRANGE calculation and the root of the tree was calibrated at $8.9 \mathrm{Ma}$, as estimated age of the most recent ancestor of all lineages of the M. sulkowskyi group. Separate analyses were also conducted to determine the ancestral root area, using local optimizations conditional on the root state (considering either single or multiple area ranges, but with only adjacent areas, following Condamine et al. (2013). Three LAGRANGE models were run: an unconstrained model, where dispersals among all areas and any combination of ancestral areas are allowed (M0), and two stepping-stone models where dispersals are prohibited between non-adjacent areas and only combinations of adjacent ancestral areas are allowed: the first with dispersal allowed only from southern to northern adjacent areas (M1), while this constraint does not exist in the second (M2).

\section{RESULTS}

\section{Field studies}

Sympatry was discovered between nieva and calderoni along the upper valley of the Nieva 
river (transect N1) and westwards at Oso Perdido (OP), while sympatry between nieva and zachi was observed downstream the Nieva (transect N2), and eastwards near El Afluente (EF) (Fig. 1). Specimens of zachi were never collected or observed with calderoni specimens, and reciprocally. Therefore, it is likely that zachi and calderoni populations are parapatric.

\section{Phylogeny and divergence time estimates}

The M. sulkowskyi group forms two clades, one including the taxa sulkowskyi, sirene and nieva (clade sulkowskyi) the other selenaris, lympharis, eros, descimokoenigi, calderoni and zachi (clade lympharis) (Fig. 2). In total, eight clusters were recognized under PTP, corresponding to sulkowskyi, sirene, nieva (two clusters), calderoni + zachi, selenaris, lympharis + descimokoenigi, and eros (Fig. 2). We selected one individual per cluster for dating analyses, except for nieva specimens, which were considered as belonging to a unique cluster. The two combined BEAST runs yielded high effective sample sizes (> 200) for all relevant parameters, indicating adequate sampling of the posterior distribution.

The Morpho sulkowskyi group diverged from the (M. portis (Hübner, [1821]) + M. aega (Hübner, [1822]) + M. aurora Westwood, 1851) clade at 14.2 Ma (95\% HPD: 18.1 - 10.4) (Fig. 3A). The subsequent divergence into the sulkowskyi clade (S, Fig. 3A) and the lympharis clade (L, Fig. 3A) occurred at 8.9 Ma (95\% HPD: 11.8-5.9 Ma). Within the sulkowskyi clade, two subclades originated at $3.9 \mathrm{Ma}$ (95\% HPD: 5.8-2.1 Ma), one corresponding to the Colombian sulkowskyi, the other to the Ecuadorian sirene and the Peruvian nieva. The divergence of nieva ancestors is estimated at 2.6 Ma (95\% HPD: 4.1-1.2 Ma). Within the lympharis clade, two subclades originated at 3.9 Ma (95\% HPD: 5.5-2.4 Ma): a northern one, corresponding to selenaris and calderoni, and a southern one, including lympharis and eros. It should be noted a topological incongruence concerning the divergence of selenaris, which possibly results from differences in molecular sampling (see Fig. 2 and 3); the dating analysis being based on mitochondrial and nuclear markers, its result will be used. The divergence of selenaris and calderoni ancestors is estimated at 3.1 Ma (95\% HPD: 4.6-1.7 Ma). Within the Peruvian-Bolivian subclade, eros ancestors diverged from lympharis ancestors at $2.4 \mathrm{Ma}$ (95\% HPD: 3.8-1.3 Ma).

\section{Biogeographical inference}


Adjacent areas optimizations recovered the Eastern Cordillera in northern Peru (ENP) as the most likely root state $(\log \mathrm{L}=-22.11)$. The M2 stepping stone model had a higher $\log$ likelihood $(\operatorname{lnL})$ than the other models $(\operatorname{lnL}=-18.04$ vs. $\operatorname{lnL}=-19.75$ for $\mathrm{M} 0$ and $\ln \mathrm{L}=-$ 22.77 for M1), and only results from this best-fitting model are reported (Fig. 3B). LAGRANGE inference suggests that the $M$. sulkowskyi and $M$. lympharis clades diverged in the northern Peruvian Andes. Later, ancestors of the M. sulkowskyi clade dispersed from northern Peru towards the Ecuadorian Andes, and subsequently towards the Colombian cordilleras (divergence between sirene and sulkowskyi subclades). The more recent divergence of nieva ancestors from the sirene lineage possibly resulted from a dispersal towards the northern end of the Peruvian Eastern Cordillera. Within the M. lympharis clade, the major event was the separation of a northern branch and a southern branch that occurred within the Peruvian Eastern Cordillera. Within the northern branch, calderoni ancestors diverged from selenaris ancestors in the northern end of the Eastern Cordillera, while eros ancestors diverged from the lympharis lineage in Bolivia (Fig. 3B).

\section{DISCUSSION}

\section{Taxonomy: towards a clarification}

The monophyly of the M. sulkowskyi group was first documented by Cassildé et al. (2012). Our results confirm the monophyly and clarify relationships between taxa. Their partition into a sulkowskyi clade and a lympharis clade is congruent with the intuition of Le Moult \& Réal (1962), who divided the Morpho sulkowskyi group into a sulkowskyi subgroup and a lympharis subgroup. Moreover, our field data show that the sulkowskyi and lympharis clades are represented by sympatric populations in the north of the Peruvian eastern Cordillera (Fig. 1). Therefore, these two clades should be considered as distinct species, according to Lamas (2004) taxonomic choice. However, the analysis from PTP resulted in eight clusters, which might be considered as different species (Fig. 2). Nevertheless, it should be emphasized that the morphologically very similar taxa sulkowskyi and sirene correspond to distinct clusters, while the morphologically different taxa zachi and calderoni are included in a single cluster, as well as are the taxa lympharis and descimokoenigi. On another hand, nieva specimens are distributed between two clusters independently of their spatial origin: in each cluster, there are specimens from N1, N2, and PN collecting areas (Fig. 1 and 2). In this context, a final 
taxonomic decision needs to be supported by several analyses with different genes, combined with morphological data and geographic distribution in an integrative taxonomy approach (Dayrat, 2005; Schlick-Steiner et al., 2010). At the moment, we adopt Lamas's viewpoint, and the studied taxa will be designated as follow: M. sulkowskyi sulkowskyi Kollar, 1849, M. sulkowskyi sirene Niepelt, 1911, M. sulkowskyi nieva Lamas \& Blandin, [2007], M. lympharis lympharis Butler, 1873, M. lympharis eros Staudinger, 1892, M. lympharis selenaris Le Moult \& Réal, 1962, and M. lympharis calderoni Blandin \& Lamas, [2007].

The origin of the group: when and where?

The M. sulkowskyi group originated between 18 and $10 \mathrm{Ma}$, according to our estimation, or even later, between 10 and 5 Ma, according to Penz et al. (2012). This incongruence between age estimations may be explained by different methodological choices. Recently, GarzónOrduña et al. (2015) emphasized the difficulties of choosing between alternative scenarios based on divergence times estimated by different secondary calibrations that may produce incompatible ages. Moreover, Van Tuinen \& Torres (2015) showed that many methodological factors influence differently the estimation of age for deep nodes and shallow nodes. Therefore, differences in species samples and calibration points may explain why we obtained an older age - ca. $48 \mathrm{Ma}$ vs ca. $32 \mathrm{Ma}$ - than Wahlberg et al. (2009). Possibly, we also overestimated other ages, including that of the M. sulkowskyi group and of subsequent divergences. However, we used a wide-outgroup approach and five secondary calibration points selected in Wahlberg et al. (2009), one of them being related to the age of a precisely dated fossil, while Penz et al. (2012) calibrated only the root of their tree, using the divergence time of the clade Morpho provided by Wahlberg et al. (2009). This method strongly underestimates divergence times, as demonstrated by Sauquet et al. (2012). Therefore, it is possible that the M. sulkowskyi group diverged earlier than Penz et al. (2012) supposed.

From a S-DIVA ancestral area reconstruction, Penz et al. (2012) concluded that $M$. sulkowskyi and its relatives M. aurora, M. aega and M. portis originated in what they called the Eastern Andean region, an immense area extending from Colombia to southern Bolivia. Blandin \& Purser (2013), taking into account the other M. sulkowskyi and M. lympharis relatives (M. absoloni May, 1924, that lives in Peruvian southern and central lowlands and Andean piedmonts, M. zephyritis, Butler, 1873, that lives along the Andes in southern Peru 
and Bolivia, from lowlands to low Andean slopes, and M. rhodopteron, Godman \& Salvin, 1880, that occurs in the Sierra Nevada de Santa Marta, northern Colombia), also concluded that the ancestors of all these species originated somewhere along the eastern side of the Andes. All these species occur at elevations lower than $2.0 \mathrm{~km}$, except M. rhodopteron that is found from 0.6 to $2.4 \mathrm{~km}$, and M. sulkowskyi and M. lympharis that live from ca. 1.8 to 3.5 km (Blandin, 2007; Blandin \& Purser, 2013). Therefore, we hypothesize that the divergence of the M. sulkowskyi group ancestors resulted from an altitudinal shift and adaptation to the cloud forest belt, in areas where altitudes suitable for the development of cloud forests were attained.

In the southern Central Andes (Bolivia - southern Peru), at least $2.0 \mathrm{~km}$ elevations were attained by ca. 20-16 Ma (Sébrier et al., 1988; Leier et al., 2013; Saylor \& Horton, 2014), and it has been suggested that cloud forests originated in this area around 20-18 Ma (Sempere et al., 2005). At that time, in northern Peru, the Western Cordillera was lower that southern ranges (Picard et al., 2008), but it attained locally $3 \mathrm{~km}$ elevations around $15 \mathrm{Ma}$ (Margirier et $a l .$, 2015). Thus, the divergence of $M$. sulkowskyi group was possible in either the southern Central Andes or the northern Western Cordillera. However, our biogeographical analysis indicates that the M. sulkowskyi group originated probably in the Eastern Cordillera, in northern Peru. Here, from ca. 24 to $17 \mathrm{Ma}$, a foredeep depozone existed in the place of the Eastern Cordillera, the uplift of which resulted from an intense horizontal shortening between $17 \mathrm{Ma}$ and $8 \mathrm{Ma}$ (Eude et al., 2015). Our estimation for the divergence time of the $M$. sulkowskyi group (ca. 18-10 Ma) is consistent with these data. However, as suitable elevations were attained towards the end of the shortening period, Penz et al. (2012) estimation (ca. 10-5 $\mathrm{Ma}$ ) is also compatible. The main point is that the group should have originated in the northern part of the Peruvian Eastern Cordilleran from low or mid-altitude ancestors, when this mountain range attained cloud forest elevations, around $10 \mathrm{Ma}$.

\section{Mio-Pliocene or Pleistocene diversification?}

The first divergence within the M. sulkowskyi group occurred during the Late Miocene, at ca. 8.9 Ma, probably a very few millions of years after the group originated in the Peruvian Eastern Cordillera. The ancestors of the sulkowskyi clade possibly dispersed towards the Western Cordillera, where cloud forests today exist in large areas near the Ecuadorian border, and southwards as restricted, isolated patches surrounded by cultivated areas (Young \& León, 
2001). This hypothesis is supported by the discovery in one of these relictual cloud forests (Cutervo area, Naranja, 2300 m; Cajamarca department), in 1998, of four males similar to Colombian and Ecuadorian specimens and consequently identified as sulkowskyi by Blandin (2007), who considered sirene as a junior synonym of sulkowskyi (these specimens are housed in MUSM; see Appendix 1, Fig. A). Such a distribution, covering the north of the Peruvian Western Cordillera and the eastern Ecuadorian cordilleras, is not surprising: it is known in other cloud forest groups, for example in the hummingbird genus Metallura Gould, 1847, which has an Andean distribution almost similar to the distribution of the M. sulkowskyi group (Benham et al., 2015).

The divergence of sulkowskyi ancestors from sirene ancestors occurred during the Pliocene, at ca. 3.9 Myr. Their common ancestors should have dispersed from the Peruvian Western Cordillera towards the Ecuadorian eastern cordilleras. Until the Middle Miocene, a lowland corridor situated approximately between $3^{\circ} \mathrm{S}$ and $5^{\circ} \mathrm{S}$, the "Western Andean Portal" (WAP) separated the Ecuadorian Andes from the Peruvian Andes (Antonelli et al., 2009; Hoorn \& Wesselingh, 2010). The WAP landscapes included wetlands, and temporary marine incursions from the Pacific Ocean might have occurred (Hungerbühler et al., 2002). Thus, the WAP constituted a long-lasting barrier for mountain organisms (Antonelli et al., 2009). Starting from 13-11 Ma, the uplift of mountain ranges closed the WAP (Coltorti \& Ollier, 2000; Hungerbühler et al., 2002). Migration of cloud forest species towards Ecuadorian and Colombian Andes became possible when suitable elevations were attained. Luebert \& Weigend (2014) quote several examples of plants that dispersed from the Central to the Northern Andes, and vice versa, during the Late Miocene and Early Pliocene, following the closure of the WAP (10-3.8 Ma). For example, the ancestors of species of the genus Puya (Bromeliaceae) that diversified in the high Northern Andes originated in the Central Andes and crossed the WAP around 6-4 Ma (Givnish et al., 2011, 2014; Jabaily \& Sytsma, 2013). We hypothesize that the ancestors of sirene and sulkowskyi lineages also crossed the WAP during this period, corresponding approximately to the Early Pliocene.

In Colombia, the Western and Central Cordilleras already had rather high elevations at the Oligocene-Miocene boundary (24-21 Ma) (Duque-Caro, 1979; Gómez et al., 2005; Roddaz et al., 2010). A major phase of uplift followed, and the rise of the Eastern Cordillera began at that time (Restrepo-Moreno et al., 2009). This cordillera reached 2.0-2.5 km elevations by 
3.7 Ma at the latitude of Bogotá (Van der Hammen \& Hooghiemstra, 2001). As we estimated the divergence of sulkowskyi ancestors from sirene ancestors at ca. 3.9 Myr, a synchronous dispersal from the eastern Ecuadorian slopes towards the three cordilleras is plausible during the Late Pliocene.

The diversification of the lympharis clade occurred during a period encompassing the Pliocene and Pleistocene, so it is difficult to differentiate the roles, on one hand of latitudinal range expansion across existing topographical barriers and subsequent allopatric divergence, on the other of the fragmentation of already established areas provoked by glacial cycles. Our results suggest a north-to-south dispersal of the lympharis lineage after its divergence, in the Peruvian Eastern Cordillera, at ca. 3.9 Ma, followed around 2.4 Ma by the divergence of the southernmost eros lineage, perhaps as a consequence of Late Pliocene or early Pleistocene climatic changes. In our present state of knowledge, we suppose that descimokoenigi populations, which are geographically separated from lympharis populations (Appendix S1), diverged during the Pleistocene.

Within the northern subclade, the divergence of calderoni ancestors also occurred during the Late Pliocene (ca. 3.1 Ma). It possibly resulted from a dispersal towards the north-eastern extremity of the Eastern Cordillera, but the role of climatic changes at the very end of the Pliocene or the beginning of the Pleistocene cannot be excluded. Our field studies provided evidence that zachi and calderoni populations are parapatric in the north-eastern extremity of the Eastern Cordillera. We hypothesize that their divergence resulted from Pleistocene fragmentation. However, it should be emphasized the fact that the easternmost mountain ranges raised during the very last few millions of years, and that they probably attained cloud forest altitudes during the Pleistocene; therefore, dispersal of cloud forest species from older ranges may have been controlled by climate-driven altitudinal shifts of ecosystems.

The divergence of nieva ancestors from the sirene lineage occurred approximately at the Pliocene-Pleistocene transition (ca. 2.6 Ma), logically in the north of the Peruvian Western Cordillera. As nieva is known only from the northernmost part of the Eastern Cordillera, which is separated from the Western Cordillera by the dry and deep Marañon valley, we hypothesize that changes in altitudinal distribution of ecological belts associated to Pleistocene climatic variations after 2.6 Ma may have favoured dispersion between the Western and the Eastern Cordilleras. 
On the whole, the expansion and diversification of the $M$. sulkowskyi group essentially occurred before the Quaternary. However, climate-driven cycles of fragmentation and expansion possibly played a role in the ultimate diversification of the group. An almost similar pattern was observed in the butterfly genus Lymanopoda Westwood, 1851 (Nymphalidae, Satyrinae), a species-rich montane group distributed along the Andes. It includes a majority of cloud forest species, the larvae of which eat montane bamboos, primarily Chusquea species (Casner \& Pyrcz, 2010). The genus first diversified between 15 and $10 \mathrm{Ma}$, the formation of major clades occurred by 10-8 Ma, and most of the species-level diversification occurred since the end of the Miocene, ca. $6 \mathrm{Ma}$, more than half of the studied species being of Pleistocene or even post-Pleistocene origin. The diversification of another high elevation (1.9-4.8 km) Andean species, the hummingbird genus Metallura followed an almost similar pattern, with Mio-Pliocene first divergences, but with the majority $(81 \%)$ of divergence events occurring during the mid-late Pleistocene (Benham et al., 2015). Thus, such examples suggest that the precise timing of diversification could differ between Andean groups, Pleistocene climatic cycles having a more or less important influence.

The origin of the group: a relationship with hostplant evolution?

Penz et al. (2012) supposed that caterpillars of all species of the clade including the $M$. sulkowskyi group and the (M. portis + . aega + M. aurora) branch feed on monocot hostplants. The hypothesis of a "monocot clade" is supported by available data for M. portis and $M$. aega, that feed on Guaduinae and Chusqueinae woody bamboos (Poaceae) (Beccaloni et al., 2008), and M. sulkowskyi that feeds on a Chusquea species (Heredia \& Alvarez, 2007). Four other species belong to the clade: M. rhodopteron, M. aurora, M. absoloni, and M. zephyritis (Cassildé et al., 2012). The former also feeds on Chusquea (Montero Abril \& Ortiz Perez, 2010). There is no published information on hostplants for the three other species; however, they are always found associated to dense stands of bamboo (G. Lamas pers. obs.), which makes it reasonable to assume their larvae feed on them. Available data indicate that all other Morpho species feed on eudicot hostplants, while other Morphinae (Antirrheina and Brassolini) feed on monocots (Beccaloni et al., 2008). Consequently, Penz et al. (2012) suggested that the Morpho clade divergence was associated to a shift to eudicotyledonous larval hostplants, and that the divergence of the monocot clade was associated to a reversal to monocot hostplants. This reversal occurred during the 25-15 Ma period (Fig. 3B), when 
Neotropical woody bamboos probably originated and began to diversify: the ancestors of Chusqueinae and Guaduinae originated during the Early-to-Middle Miocene (ca. 21-11 Ma), probably in the Andes (Fisher, 2011; Ruiz-Sanchez, 2011).

Heredia \& Alvarez (2007) observed that the Colombian M. sulkowskyi feeds, at 2.4-2.5 km a.s.1., on a species closely related to Chusquea scandens Kunth, 1822 one of the five Chusquea species distributed from Bolivia to Colombia (Ohrnberger, 1999). The clade including C. scandens diverged between ca 14.5 and 6.5 Myr (Fisher, 2011); our estimation of the age of the M. sulkowskyi group is consistent with this information.

\section{CONCLUSIONS}

Simple relationships between Andean uplift and the diversification of various plant and animal groups, implying pre-Pleistocene driving processes, have been supposed by various authors. Doan (2003), for example, proposed the South-to-North Speciation Hypothesis, where the process of speciation should be related to the south-to-north progression of uplift throughout the Andes. Other authors emphasized the possible role of a rapid uplift that occurred during the Late Miocene and Early Pliocene, but often without establishing clear links between dated divergences and local geologic events (e.g., Casner \& Pyrcz, 2010; Mulch et al., 2010; Matos-Maraví et al., 2013; Lagomarsino et al., 2016). From a geological point of view, the concept of a progressive, general south-to-north uplift is an oversimplified view of a much more complex reality (Sempere et al., 2008). In the Central Andes, palaeoelevation histories differ not only between the south and the north, but also between the Western and the Eastern Cordilleras, notably in northern Peru (Picard et al., 2008; Eude et al., 2015; Margirier et al., 2015). The idea that the Northern Andes, as a whole, uplifted later than the Central Andes, as suggested by Doan (2003), and often admitted by other authors, is not supported by geological studies, that also demonstrate that the timing of palaeo-elevation differed between the three Colombian Cordilleras (Restrepo-Moreno et al., 2009). Consistent with many other examples, notably the clearwing Oleriina butterflies (De-Silva et al., 2016), the M. sulkowskyi group illustrates the diversity of diversification histories throughout the Andes. It also demonstrates that Mio-Pliocene orogenic and Pleistocene climatic diversification drivers should not be opposed. 


\section{Acknowledgements}

This work was conducted within the framework of a cooperation agreement between the Muséum National d'Histoire Naturelle (Paris) and the Museo de Historia Natural, Universidad Nacional Mayor de San Marcos (Lima). It was part of the project "Géographie de la Biodiversité des Lépidoptères dans le nord du Pérou", which received financial support from the Muséum National d'Histoire Naturelle (Programme Pluri-Formations "Etat et structure phylogénétique de la biodiversité actuelle et fossile", 2005-2009). This work is part of the project @ SPEED-ID "Accurate SPEciEs Delimitation and IDentification of eukaryotic biodiversity using DNA markers" proposed by F-BoL, the French Barcode of Life initiative. This work was made possible thanks to research permits granted by the Dirección de Gestión Forestal y de Fauna Silvestre and the Dirección General Forestal y de Fauna Silvestre, Ministerio de Agricultura y Riego, Peru (autorizaciones: 012-2008-INRENA-IFFS-DCB; 082009-AG-DGFFS; 0089-2010-AG-DGFFS-DGEFFS； 0201-2011-AG-DGFFS-DGEFFS; 0201-2013-MINAGRI-DGFFS/DGEFFS). We thank Amanda Fisher for providing her thesis chapter on Chusquea evolution, and for interesting discussions, Jean-François Le Crom, and Stéphane Attal for information on localities in Colombia and Ecuador. At different steps of the drafting process, Marianne Elias, Nicolas Chazot, Mathieu Chouteau, and Fabien Condamine provided useful comments and methodological suggestions. Mathieu Chouteau also contributed to the preparation of the map in Fig. 1. We also warmly thank Thierry Sempere and Martin Roddaz for stimulating discussions on the highly complex history of the Andes, for providing specialized geological literature, and for reviewing a first draft of the manuscript. We also thank Helen McCombie for improving the English.

\section{References}

Adams M.J. (1985). Speciation in the pronophiline butterflies (Satyridae) of the northern Andes. Journal of Research on the Lepidoptera, 1985, 33-49.

Akaike H. (1973). Information theory and an extension of the maximum likelihood principle. Proceedings of the Second International Symposium on Information Theory, 1, 267-281.

Akaike H. (1974). New Look at Statistical-Model Identification. Ieee Transactions on Automatic Control, Ac19, $716-723$.

Antonelli A., Nylander J.A., Persson C., \& Sanmartín I. (2009). Tracing the impact of the Andean uplift on Neotropical plant evolution. Proceedings of the National Academy of Sciences, 106, 9749-9754. 
Beccaloni G.W., Viloria A.L., Hall S.K., \& Robinson G.S. (2008). Catalogue of the Hostplants of the Neotropical Butterflies. The Natural History Museum, London.

Benham P.M., Cuervo A.M., McGuire J.A., \& Witt C.C. (2015). Biogeography of the Andean metaltail hummingbirds: contrasting evolutionary histories of tree line and habitat-generalist clades. Journal of Biogeography, 42, 763-777.

Blandin P. (1993). The genus Morpho, Lepidoptera Nymphalidae. Part 2. The subgenera Iphixibia, Cytheritis, Balachowskyna, and Cypritis. Venette: Sciences Nat.

Blandin P. (2007). The Systematics of the Genus Morpho, Fabricius, 1807 (Lepidoptera Nymphalidae: Morphinae). Canterbury: Hillside Books.

Blandin P. \& Lachaume G. (2014). La découverte des Morpho dans le Pérou septentrional, de la fin du XIXe au début du XXIe siècle. Antenor, 1, 199-261.

Blandin P. \& Purser B. (2013). Evolution and diversification of Neotropical butterflies: Insights from the biogeography and phylogeny of the genus Morpho Fabricius, 1807 (Nymphalidae: Morphinae), with a review of the geodynamics of South America. Tropical Lepidoptera Research, 23, 62-85.

Casner K.L. \& Pyrcz T.W. (2010). Patterns and timing of diversification in a tropical montane butterfly genus, Lymanopoda (Nymphalidae, Satyrinae). Ecography, 33, 251-259.

Cassildé C., Blandin P., Pierre J., \& Bourgoin T. (2010). Phylogeny of the genus Morpho Fabricius, 1807, revisited (Lepidoptera, Nymphalidae). Bulletin de la Société Entomologique de France, 115, 225-250.

Cassildé C., Blandin P., \& Silvain J.-F. (2012). Phylogeny of the genus Morpho Fabricius 1807: insights from two mitochondrial genes (Lepidoptera: Nymphalidae). Annales de la Société Entomologique de France, 48, 173-188.

Castroviejo-Fisher S., Guayasamin J.M., Gonzalez-Voyer A., \& Vilà C. (2014). Neotropical diversification seen through glassfrogs. Journal of Biogeography, 41, 66-80.

Chaves J.A., Weir J.T., \& Smith T.B. (2011). Diversification in Adelomyia hummingbirds follows Andean uplift. Molecular Ecology, 20, 4564-4576.

Chesser R.T. (2000). Evolution in the High Andes: The Phylogenetics of Muscisaxicola Ground-Tyrants. Molecular Phylogenetics and Evolution, 15, 369-380.

Coltorti M. \& Ollier C.D. (2000). Geomorphic and tectonic evolution of the Ecuadorian Andes. Geomorphology, $32,1-19$

Condamine F.L., Silva-Brandão K.L., Kergoat G.J., \& Sperling F.A. (2012). Biogeographic and diversification patterns of Neotropical Troidini butterflies (Papilionidae) support a museum model of diversity dynamics for Amazonia. BMC evolutionary biology, 12, 82.

Condamine F.L., Soldati L., Clamens A.-L., Rasplus J.-Y., \& Kergoat G.J. (2013). Diversification patterns and processes of wingless endemic insects in the Mediterranean Basin: historical biogeography of the genus Blaps (Coleoptera: Tenebrionidae). Journal of Biogeography, 40, 1899-1913.

Couvreur T.L., Forest F., \& Baker W.J. (2011). Origin and global diversification patterns of tropical rain forests: inferences from a complete genus-level phylogeny of palms. BMC biology, 9, 44.

Darriba D., Taboada G.L., Doallo R., \& Posada D. (2012). jModelTest 2: more models, new heuristics and parallel computing. Nature Methods, 9, 772-772.

Dayrat B. (2005). Towards integrative taxonomy. Biological Journal of the Linnean Society, 85, 407-415. 
Descimon H. (1986). Origins of lepidopteran faunas in the high tropical Andes. In F. Vuilleumier \& M. Monasterio (Eds) High altitude tropical biogeography (pp. 500-532). New-York: Oxford University Press.

De-Silva D.L., Elias M., Willmott K., Mallet J., \& Day J.J. (2016). Diversification of clearwing butterflies with the rise of the Andes. Journal of Biogeography, 43, 44-58.

Doan T.M. (2003). A south-to-north biogeographic hypothesis for Andean speciation: evidence from the lizard genus Proctoporus (Reptilia, Gymnophthalmidae). Journal of Biogeography, 30, 361-374.

Drummond A.J., Suchard M.A., Xie D., \& Rambaut A. (2012). Bayesian phylogenetics with BEAUti and the BEAST 1.7. Molecular Biology and Evolution, 29, 1969-1973.

Duque-Caro H. (1979). Major structural elements and evolution of northwestern Colombia. Geological and geophysical investigations of continental margins: AAPG Memoir, 29, 329-351.

Elias M., Joron M., Willmott K., Silva-Brandao K.L., Kaiser V., Arias C.F., Pinerez L.M.G., Uribe S., Brower A.V.Z., Freitas A.V.L., \& Jiggins C.D. (2009). Out of the Andes: patterns of diversification in clearwing butterflies. Molecular Ecology, 18, 1716-1729.

Eude A., Roddaz M., Brichau S., Brusset S., Calderon Y., Baby P., \& Soula J.-C. (2015). Controls on timing of exhumation and deformation in the northern Peruvian eastern Andean wedge as inferred from low-temperature thermochronology and balanced cross section. Tectonics, 34, 715-730.

Fiedler K. \& Strutzenberger P. (2013). Past Dynamics of Speciation in Andean Mountain Rainforests. In J. Bendix, E. Beck, A. Bräuning, F. Makeschin, R. Mosandl, S. Scheu, \& W. Wilcke (Eds) Ecosystem Services, Biodiversity and Environmental Change in a Tropical Mountain Ecosystem of South Ecuador (pp. 67-79). Berlin: Springer.

Fisher A.E. (2011). Phylogenetic studies of plastid evolution in the neotropical woody bamboo genus Chusquea (Poaceae: Bambusoideae: Bambusae). PhD Thesis, Idaho State University, Idaho.

García-Moreno J., Arctander P., \& Fjeldså J. (1999). A Case of Rapid Diversification in the Neotropics: Phylogenetic Relationships among Cranioleuca Spinetails (Aves, Furnariidae). Molecular Phylogenetics and Evolution, 12, 273-281.

Garzione C.N., Hoke G.D., Libarkin J.C., Withers S., MacFadden B., Eiler J., Ghosh P., \& Mulch A. (2008). Rise of the Andes. Science, 320, 1304-1307.

Garzón-Orduña I.J., Benetti-Longhini J.E., \& Brower A.V.Z. (2014). Timing the diversification of the Amazonian biota: butterfly divergences are consistent with Pleistocene refugia. Journal of Biogeography, 41, 1631-1638.

Garzón-Orduña I.J., Silva-Brandão K.L., Willmott K.R., Freitas A.V.L., \& Brower A.V.Z. (2015). Incompatible ages for clearwing butterflies based on alternative secondary calibrations. Systematic Biology, 752-767.

Givnish T.J., Barfuss M.H.J., Ee B.V., Riina R., Schulte K., Horres R., Gonsiska P.A., Jabaily R.S., Crayn D.M., Smith J.A.C., Winter K., Brown G.K., Evans T.M., Holst B.K., Luther H., Till W., Zizka G., Berry P.E., \& Sytsma K.J. (2011). Phylogeny, adaptive radiation, and historical biogeography in Bromeliaceae: Insights from an eight-locus plastid phylogeny. American Journal of Botany, 98, 872895.

Givnish T.J., Barfuss M.H.J., Ee B.V., Riina R., Schulte K., Horres R., Gonsiska P.A., Jabaily R.S., Crayn D.M., Smith J.A.C., Winter K., Brown G.K., Evans T.M., Holst B.K., Luther H., Till W., Zizka G., Berry P.E., \& Sytsma K.J. (2014). Adaptive radiation, correlated and contingent evolution, and net species diversification in Bromeliaceae. Molecular Phylogenetics and Evolution, 71, 55-78.

Gómez E., Jordan T.E., Allmendinger R.W., \& Cardozo N. (2005). Development of the Colombian forelandbasin system as a consequence of diachronous exhumation of the northern Andes. Geological Society of America Bulletin, 117, 1272-1292. 
Hall J.P. (2005). Montane speciation patterns in Ithomiola butterflies (Lepidoptera: Riodinidae): are they consistently moving up in the world? Proceedings of the Royal Society B: Biological Sciences, 272, 2457-2466.

Hedges S.B. \& Kumar S. (2004). Precision of molecular time estimates. Trends in Genetics, 20, $242-247$.

Heredia M.D. \& Alvarez H. (2007). Biología y conservación de Morpho sulkowskyi en Colombia (Lepidoptera: Nymphalidae: Morphinae). Tropical Lepidoptera, 16, 11-21.

Ho S.Y.W. (2007). Calibrating molecular estimates of substitution rates and divergence times in birds. Journal of Avian Biology, 38, 409-414.

Ho S.Y.W., Phillips M.J., Cooper A., \& Drummond A.J. (2005). Time dependency of molecular rate estimates and systematic overestimation of recent divergence times. Molecular Biology and Evolution, 22, 15611568 .

Hoorn C., Mosbrugger V., Mulch A., \& Antonelli A. (2013). Biodiversity from mountain building. Nature Geoscience, 6, 154-154.

Hoorn C. \& Wesselingh F. (2010). Amazonia: Landscape and Species Evolution. A Look into the Past. UK, Sussex: Wiley-Blackwell.

Hungerbühler D., Steinmann M., Winkler W., Seward D., Egüez A., Peterson D.E., Helg U., \& Hammer C. (2002). Neogene stratigraphy and Andean geodynamics of southern Ecuador. Earth-Science Reviews, $57,75-124$.

Jabaily R.S. \& Sytsma K.J. (2013). Historical biogeography and life-history evolution of Andean Puya (Bromeliaceae). Botanical Journal of the Linnean Society, 171, 201-224.

Krüger E. (1924). Die Morphiden Kolumbiens nebst einigen allgemeinen Bemerkungen über Morphiden. Deutsche entomologische Zeitschrift “Iris, ” 99-132.

Lagomarsino L.P., Condamine F.L., Antonelli A., Mulch A., \& Davis C.C. (2016). The abiotic and biotic drivers of rapid diversification in Andean bellflowers (Campanulaceae). New Phytologist, 210, 1430-1442.

Lamas G. (2004). Morphinae. In G. Lamas (Ed) Checklist: Part 4A. Hesperioidea - Papilionoidea, Atlas of Neotropical Lepidoptera (pp. 192-205). Florida, Gainesville: Association for tropical Lepidoptera/ Scientific Publishers.

Le Moult E. \& Réal P. (1962). Les Morpho D’Amérique du Sud et Centrale. Novitates Entomologicae (supplément). Editions du Cabinet Entomologique E. Le Moult, Paris, France.

Lee M.S.Y. (1999). Molecular clock calibrations and metazoan divergence dates. Journal of Molecular Evolution, 49, 385-391.

Leier A., McQuarrie N., Garzione C., \& Eiler J. (2013). Stable isotope evidence for multiple pulses of rapid surface uplift in the Central Andes, Bolivia. Earth and Planetary Science Letters, 371-372, 49-58.

Luebert F. \& Muller L.A.H. (2015). Effects of mountain formation and uplift on biological diversity. Frontiers in Genetics, 6, 54.

Luebert F. \& Weigend M. (2014). Phylogenetic insights into Andean plant diversification. Evolutionary and Population Genetics, 2, 27.

Margirier A., Robert X., Audin L., Gautheron C., Bernet M., Hall S., \& Simon-Labric T. (2015). Slab flattening, magmatism, and surface uplift in the Cordillera Occidental (northern Peru). Geology, 43, 1031-1034.

Matos-Maraví P.F., Peña C., Willmott K.R., Freitas A.V.L., \& Wahlberg N. (2013). Systematics and evolutionary history of butterflies in the "Taygetis clade" (Nymphalidae: Satyrinae: Euptychiina): 
Towards a better understanding of Neotropical biogeography. Molecular Phylogenetics and Evolution, 66, 54-68.

Miller J.Y., Miller L.D., \& Ivie M.A. (2012). A New Lepidopteran Fossil from the Canyon Ferry Reservoir Deposit in Southwestern Montana (Lepidoptera: Nymphalidae: Satyrinae). Bulletin of the Allyn Museum, 167, 1-12.

Mittermeier R.A., Robles Gil P., Hoffmann M., Pilgrim J., Brooks T., Goettsch Mittermeier C., Lamoreux J., \& Da Fonseca G.A.B. (2004). Hotspots revisited. Mexico: CEMEX.

Montero Abril F. \& Ortiz Perez M. (2010). Descripción de los estados immaduros de Morpho rhodopteron nevadensis (Lepidoptera: Nymphalidae: Morphinae). Tropical Lepidoptera Research, 20, 71-76.

Mulch A., Uba C.E., Strecker M.R., Schoenberg R., \& Chamberlain C.P. (2010). Late Miocene climate variability and surface elevation in the central Andes. Earth and Planetary Science Letters, 290, 173182.

Ohrnberger D. (1999). The Bamboos of the World. Annotated Nomenclature and Literature of the Species and the Higher and Lower Taxa. Amsterdam: Elsevier Science.

Pennington R.T. \& Dick C.W. (2004). The role of immigrants in the assembly of the South American rainforest tree flora. Philosophical Transactions of the Royal Society of London. Series B: Biological Sciences, 359, 1611-1622.

Penz C.M., Devries P.J., \& Wahlberg N. (2012). Diversification of Morpho butterflies (Lepidoptera, Nymphalidae): a re-evaluation of morphological characters and new insight from DNA sequence data. Systematic Entomology, 37, 670-685.

Picard D., Sempere T., \& Plantard O. (2008). Direction and timing of uplift propagation in the Peruvian Andes deduced from molecular phylogenetics of highland biotaxa. Earth and Planetary Science Letters, 271, 326-336.

Prieto C., Takegami C., \& Rivera J.M. (2005). Estructura poblacional de Morpho sulkowskyi Kollar, 1850 (Lepidoptera: Nymphalidae) en un sector de la cordillera occidental, departamento del Cauca (Colombia). Entomotropica, 20, 15-22.

Rambaut A. \& Drummond A.J. (2007). Tracer v1.4. Available at: http://beast.bio.ed.ac.uk/tracer.

Ree R.H., Moore B.R., Webb C.O., \& Donoghue M.J. (2005). A likelihood framework for inferring the evolution of geographic range on phylogenetic trees. Evolution, 59, 2299-2311.

Ree R.H. \& Smith S.A. (2007). Lagrange (Software for likelihood analysis of geographic range evolution). Version 2. Distributed by the authors at http://lagrange.googlecode.com,

Restrepo-Moreno S.A., Foster D.A., Stockli D.F., \& Parra-Sánchez L.N. (2009). Long-term erosion and exhumation of the "Altiplano Antioqueño", Northern Andes (Colombia) from apatite (U-Th)/He thermochronology. Earth and Planetary Science Letters, 278, 1-12.

Roddaz M., Hermoza W., Mora A., Baby P., Parra M., Christophoul F., Brusset S., Espurt N., Hoorn C., \& Wesselingh F.P. (2010). Cenozoic sedimentary evolution of the Amazonian foreland basin system. In C. Hoorn \& F.P. Wesselingh (Eds) Amazonia, Landscape and Species Evolution: A look into the Past. (pp. 61-88). Hoboken: Blackwell-Wiley.

Ronquist F. \& Huelsenbeck J.P. (2003). MrBayes 3: Bayesian phylogenetic inference under mixed models. Bioinformatics, 19, 1572-1574.

Ruiz-Sanchez E. (2011). Biogeography and divergence time estimates of woody bamboos: insights in the evolution of Neotropical bamboos. Boletín de la Sociedad Botánica de México, 88, 67-75. 
Rull V. (2008). Speciation timing and neotropical biodiversity: the Tertiary-Quaternary debate in the light of molecular phylogenetic evidence. Molecular Ecology, 17, 2722-2729.

Rull V. (2014). Biodiversity, mountains and climate change. Collectanea Botanica, 33, e006.

Salazar J.A. (1998). Contribución al conocimiento de los Morphinae colombianos. IV. Estudio de una población de Morpho sulkowskyi Kollar 1850, en el centro de Colombia (Lepidoptera: Nymphalidae: Morphinae). SHILAP, 26, 113-116.

Sanín M.J., Kissling W.D., Bacon C.D., Borchsenius F., Galeano G., Svenning J.-C., Olivera J., Ramírez R., Trénel P., \& Pintaud J.-C. (2016). The Neogene rise of the tropical Andes facilitated diversification of wax palms (Ceroxylon: Arecaceae) through geographical colonization and climatic niche separation. Botanical Journal of the Linnean Society, n/a-n/a.

Sauquet H., Ho S.Y., Gandolfo M.A., Jordan G.J., Wilf P., Cantrill D.J., Bayly M.J., Bromham L., Brown G.K., \& Carpenter R.J. (2012). Testing the impact of calibration on molecular divergence times using a fossilrich group: the case of Nothofagus (Fagales). Systematic Biology, 61, 289-313.

Saylor J.E. \& Horton B.K. (2014). Nonuniform surface uplift of the Andean plateau revealed by deuterium isotopes in Miocene volcanic glass from southern Peru. Earth and Planetary Science Letters, 387, 120 131.

Schlick-Steiner B.C., Steiner F.M., Seifert B., Stauffer C., Christian E., \& Crozier R.H. (2010). Integrative Taxonomy: A Multisource Approach to Exploring Biodiversity. Annual Review of Entomology, 55, 421-438.

Schultze A. (1928). Beobachtungen und Betrachtungen über zwei in ihren Existenz gefährdete Morpho-Arten Kolumbiens, Morpho rhodopteron v. nevadensis und M. sulkowskyi. Deutsche entomologische Zeitschrift "Iris," 246-268.

Sébrier M., Lavenu A., Fornari M., \& Soulas J.P. (1988). Tectonics and uplift in Central Andes (Peru, Bolivia and northern Chile) from Eocene to present. Géodynamique, 3, 85-106.

Sempere T., Folguera A., \& Gerbault M. (2008). New insights into Andean evolution: An introduction to contributions from the 6th ISAG symposium (Barcelona, 2005). Tectonophysics, 459, 1-13.

Sempere T., Picard D., \& Plantard O. (2005). Assessing and dating andean uplift by phylogeography and phylochronology: early miocene emergence of Andean cloud forests. 6th International Symposium on Andean Geodynamics (ISAG 2005, Barcelona), Extended Abstracts, 663-665.

Strijk J.S., Noyes R.D., Strasberg D., Cruaud C., Gavory F., Chase M.W., Abbott R.J., \& Thébaud C. (2012). In and out of Madagascar: Dispersal to Peripheral Islands, Insular Speciation and Diversification of Indian Ocean Daisy Trees (Psiadia, Asteraceae). PLoS ONE, 7, e42932.

Strutzenberger P. \& Fiedler K. (2011). Temporal patterns of diversification in Andean Eois, a species-rich clade of moths (Lepidoptera, Geometridae). Journal of Evolutionary Biology, 24, 919-925.

van Tuinen M. \& Torres C.R. (2015). Potential for bias and low precision in molecular divergence time estimation of the Canopy of Life: an example from aquatic bird families. Frontiers in Genetics, 203.

Turchetto-Zolet A.C., Pinheiro F., Salgueiro F., \& Palma-Silva C. (2013). Phylogeographical patterns shed light on evolutionary process in South America. Molecular Ecology, 22, 1193-1213.

Van der Hammen T. \& Hooghiemstra H. (2001). Historia y paleoecología de los bosques montanos andinos neotropicales. In M. Kappelle \& A.D. Brown (Eds) Bosques nublados del neotrópico (pp. 63-84). Costa Rica: Instituto Nacional de Biodiversidad.

Wahlberg N. \& Freitas A.V. (2007). Colonization of and radiation in South America by butterflies in the subtribe Phyciodina (Lepidoptera: Nymphalidae). Molecular phylogenetics and evolution, 44, 1257-1272. 
Wahlberg N., Leneveu J., Kodandaramaiah U., Peña C., Nylin S., Freitas A.V., \& Brower A.V. (2009). Nymphalid butterflies diversify following near demise at the Cretaceous/Tertiary boundary. Proceedings of the Royal Society B: Biological Sciences, 276, 4295-4302.

Wang D.Y.C., Kumar S., \& Hedges S.B. (1999). Divergence time estimates for the early history of animal phyla and the origin of plants, animals and fungi. Proceedings of the Royal Society B: Biological Sciences, 266, 163-171.

Willmott K.R., Hall J.P., \& Lamas G. (2001). Systematics of Hypanartia (Lepidoptera: Nymphalidae: Nymphalinae), with a test for geographical speciation mechanisms in the Andes. Systematic Entomology, 26, 369-399.

Zhang J., Kapli P., Pavlidis P., \& Stamatakis A. (2013). A general species delimitation method with applications to phylogenetic placements. Bioinformatics, 29, 2869-2876.

\section{Figures}

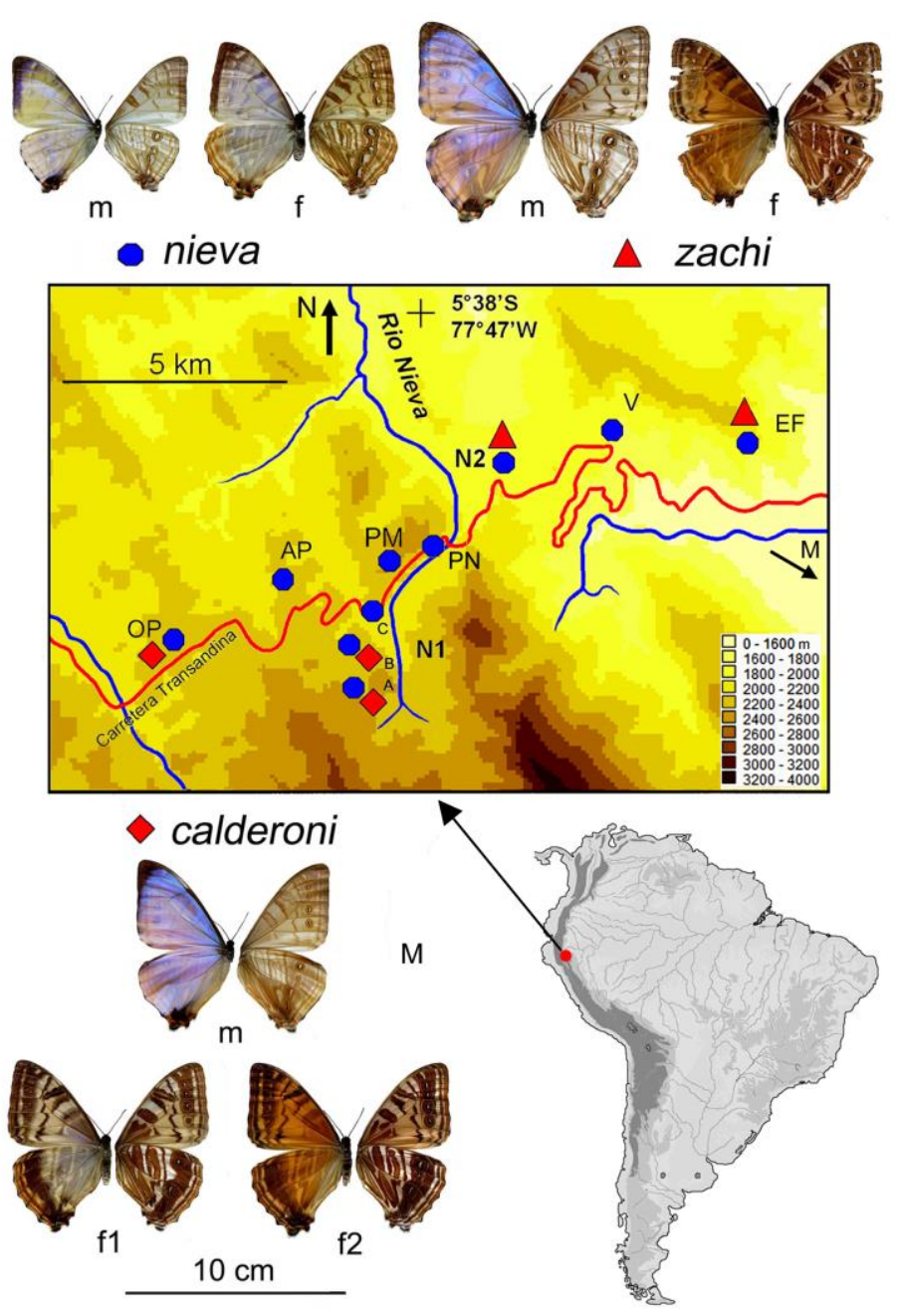


Figure 1. Map of the region where field studies were carried out, with habitus of the taxa calderoni, zachi and nieva (m: male; f: female; f1 and f2: female morphs within the calderoni population). N1 and N2: sampling areas along the upper Río Nieva. Other localities where specimens were collected: AP: Abra Patricia; EF: El Afluente; OP: Oso Perdido; PM: Abra Pardo Miguel; V: Venceremos. Two specimens of nieva were also collected at Santa Cruz del Mirador (M), at 20 km ESE from El Afluente.

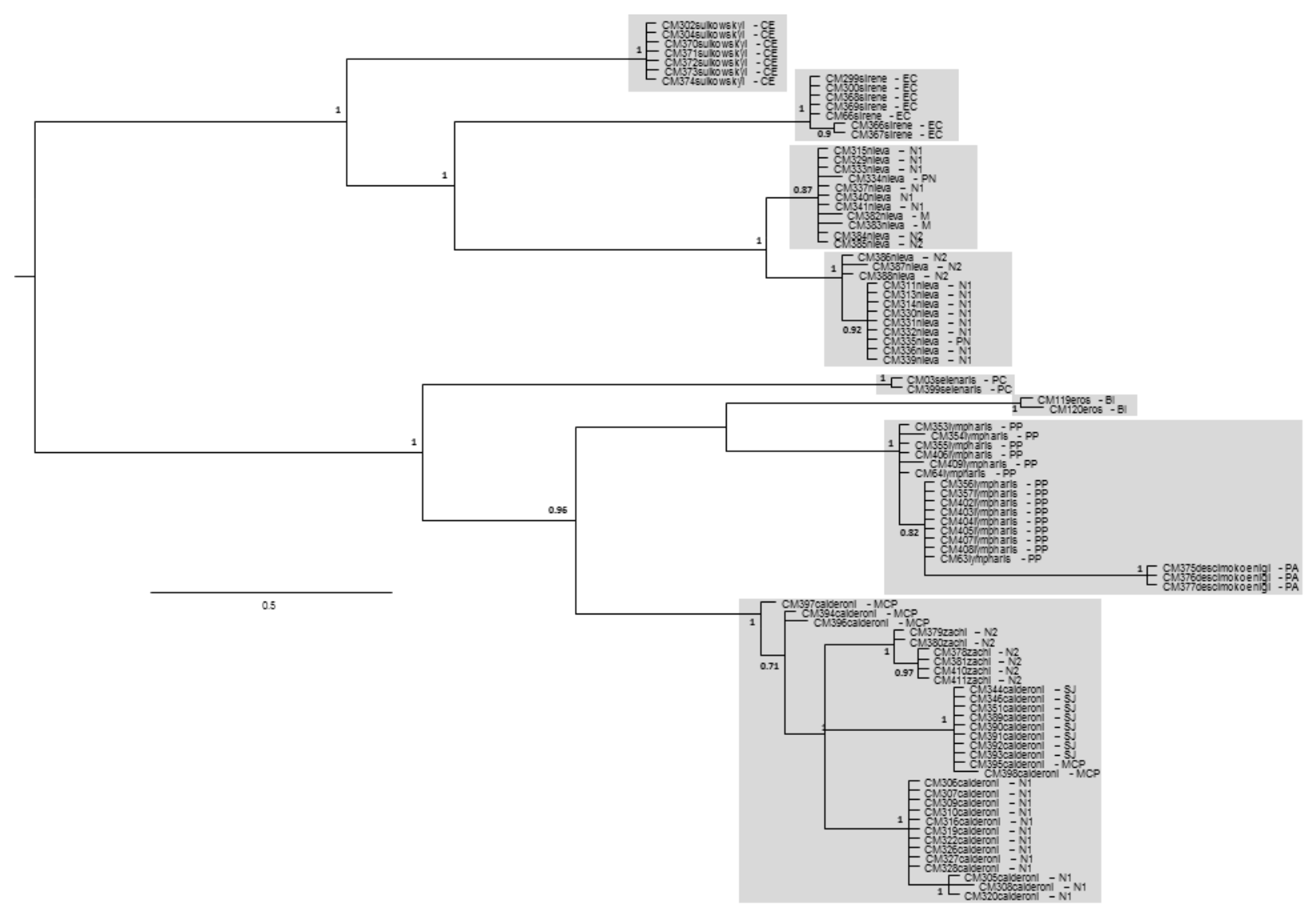

Figure 2. Topology obtained by Bayesian inference and clusters recognized after analyses conducted for Cytb on the PTP web server (http://species.h-its.org/ptp). 
(A)
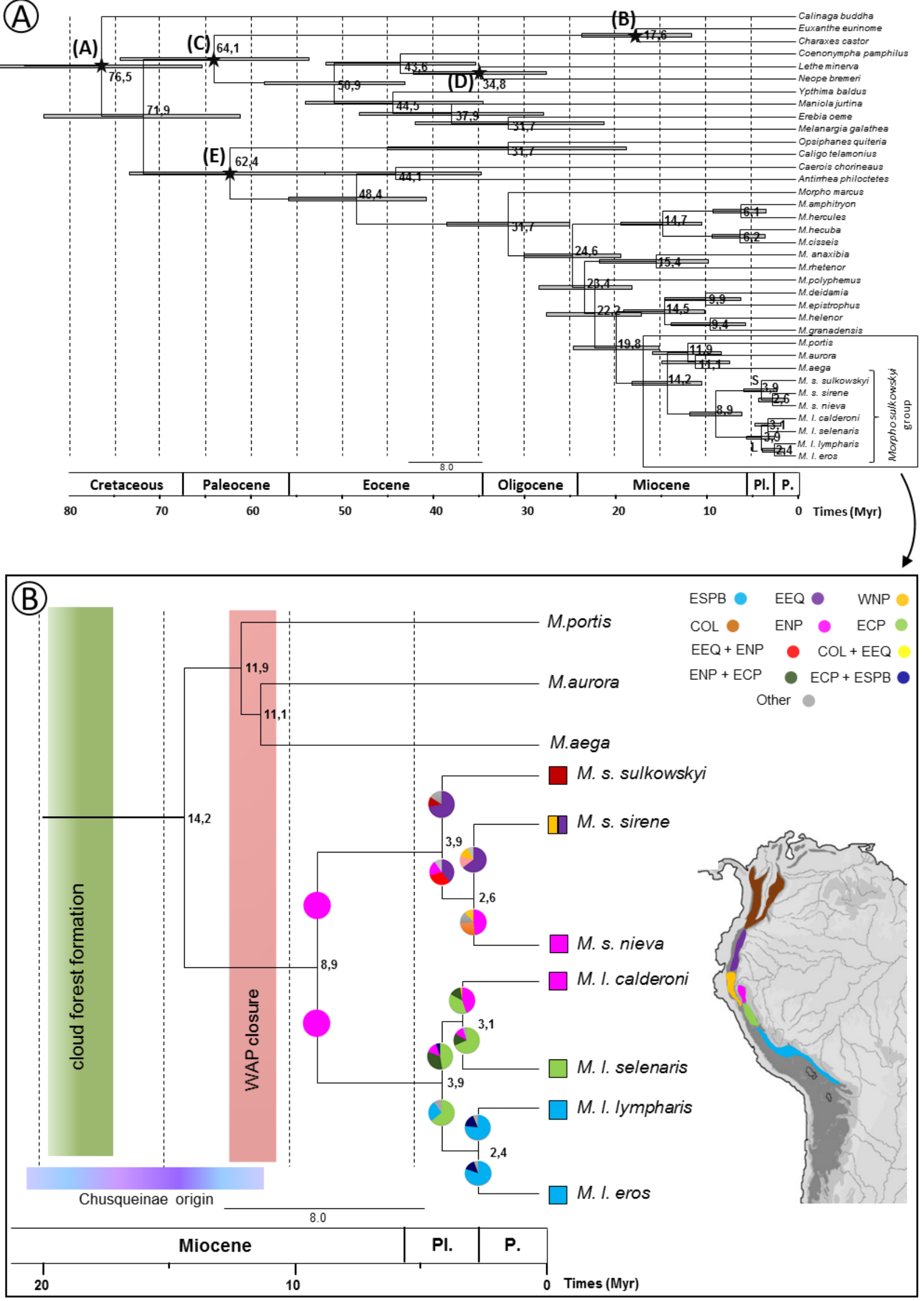
Figure 3. A) Chronogram representing the divergence times of the principal lineages of nymphalid butterflies including the Morpho sulkowskyi group. B) Chronogram representing the divergence times of the Morpho sulkowskyi group. Node positions indicate mean estimated divergence times, and pie charts represent relative probabilities of ancestral ranges.

\section{Supporting Information}

Additional Supporting Information may be found in the online version of this article:

Appendix S1. The Morpho sulkowskyi group: geographical distribution and taxonomy.

Appendix S2. List of all taxa included in the analyses and their Genbank accession numbers: a - phylogenetic analysis and species delimitation; b - dating analysis. In GenBank, geographical origins of many specimens are not available (n/a).

Appendix S3. Additional information on sequencing protocols. 